\title{
Enantioselective Synthesis of $\beta$-Amino Acids. 12. Experimental and Theoretical Study of the Diastereoselectivity of Alkylation of the Dianion of $N^{\prime}, N^{\prime}-B i s(\alpha$-phenylethyl)- $N$ - carbobenzyloxypropionamide.
}

\author{
Víctor Manuel Gutiérrez-García, Gloria Reyes-Rangel, Omar Muñoz-Muñiz and Eusebio Juaristi* \\ Departamento de Química, Centro de Investigación y de Estudios Avanzados del Instituto Politécnico Nacional, \\ Apartado Postal 14-740, 07000, México, D.F. (México)
}

\begin{abstract}
$\beta$-Alanina, matéria-prima aquiral e de baixo custo, foi convertida na amida quiral 1 em $53 \%$ de rendimento global. A alquilação de $(R, R)$-1 requereu a formação de seu diânion, $(R, R)-\mathbf{1}-\mathrm{Li}_{2}$ que foi alcançada de maneira mais eficiente pela metação direta com dois equivalentes de $n$-BuLi em solução de THF a $-78^{\circ} \mathrm{C}$. O tratamento de $(R, R)-1-\mathrm{Li}_{2}$ com vários haletos de alquila forneceu os produtos monoalquilados 3-6 em 24-85\% de rendimento e $65-86 \%$ de diastereosseletividade. $\mathrm{O}$ efeito do aditivo $\mathrm{LiCl}$ ou de HMPA como co-solvente na diastereosseletividade da reação de alquilação foi essencialmente desprezível, embora os reandimentos tenham geralmente aumentado. A correlação química do diastereoisômero majoritário da reação de metilação com $(S)$ - $\alpha$-metil- $\beta$ alanina mostra que a adição do eletrófilo ocorre preferencialmente na face $S i$ do enolato. Esta conclusão é também apoiada por estudos de modelagem molecular (ab initio HF/3-21G) que indicam que a conformação de menor energia para $(R, R)-\mathbf{1}-\mathrm{Li}_{2}$ apresenta a face $R e$ do enolato mais impedida estericamente. Os estudos teóricos também ofereceram indicações úteis sobre a importância da ligação de hidrogênio e de interações atrativas $\pi-\pi$ em $(R, R)-\mathbf{1}$. Adicionalmente, os cálculos prevêem um papel determinante para a quelação $\mathrm{N}-\mathrm{Li}-\mathrm{O}$ em $(R, R)$-1-Li assim como um interessante configuração de tripleto iônico para o diânion de lítio $(R, R)-\mathbf{1}-\mathrm{Li}_{2}$.
\end{abstract}

Achiral, inexpensive $\beta$-alanine was converted into the title chiral amide $\mathbf{1}$ in $53 \%$ overall yield. $C$-Alkylation of $(R, R)-\mathbf{1}$ required formation of its dianion derivative, $(R, R)-\mathbf{1}-\mathrm{Li}_{2}$, which was best achieved by direct metallation with two equivalents of $n$-BuLi in THF solution and at $-78^{\circ} \mathrm{C}$. Treatment of $(R, R)-1-\mathrm{Li}_{2}$ with various alkyl halides afforded the monoalkylated products 3-6 in 24-85\% yield and 65-86\% diastereoselectivity. The effect of $\mathrm{LiCl}$ additive or HMPA cosolvent on the diastereoselectivity of the alkylation reaction was essentially negligible, although reaction yields generally improved. Chemical correlation of the major diastereomer from the methylation reaction with $(S)-\alpha$-methyl- $\beta$-alanine shows that addition of the electrophile takes place preferentially on the enolate's $S i$ face. This conclusion is also supported by molecular modelling studies (ab initio HF/3-21G), which indicate that the conformation of lowest energy for $(R, R)-1-\mathrm{Li}_{2}$ presents a more sterically hindered $R e$ face of the enolate. The theoretical studies also provided useful insight into the importance of hydrogen bonding and attractive $\pi-\pi$ interactions in $(R, R)$-1. Furthermore, the calculations predict a determining role for $\mathrm{N}-\mathrm{Li}-\mathrm{O}$ chelation in $(R, R)-\mathbf{1}-\mathrm{Li}$, as well as an interesting ion triplet configuration for dilithium dianion $(R, R)-\mathbf{1}-\mathrm{Li}_{2}$.

Keywords: Amino acids, diastereoselective alkylation, enolates, theoretical studies.

\section{Introduction}

During the last few years, the preparation of enantiopure $\beta$-amino acids has emerged as an important and challenging synthetic endeavor. The increasing attention given to the chemistry of $\beta$-amino acids is partly due to the fact that they are components of a variety of natural products such as taxol ${ }^{1}$,

* e-mail: juaristi@relaq.mx the dolastatins ${ }^{2}$, and many others ${ }^{3}$. Furthermore, a number of $\beta$-amino acids show interesting pharmacological properties in free form ${ }^{4}$, or as their cyclized ( $\beta$-lactam) derivatives $^{5}$. Also, a number of research groups have embarked on the synthesis of oligomers from $\beta$-amino acids, which give rise to stabilized helical structures and can exhibit a resistance to enzymatic hydrolysis ${ }^{6}$.

Much of the work pertaining enantioselective synthesis of $\beta$-amino acids has been reviewed ${ }^{7}$. Recently, the potential 
<smiles>CC(c1ccccc1)N(C(=O)CCN(Cc1ccccc1)C1CCCCC1)C(C)c1ccccc1</smiles>

A, Juaristi, ref. $8 \mathrm{c}$

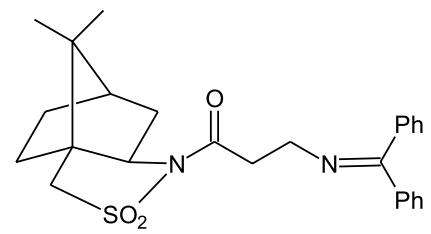

C, Lavielle, ref. 8a<smiles>COC(=O)CCN(Cc1ccccc1)[C@@H](C)c1ccccc1</smiles>

B, Juaristi, ref. $8 \mathrm{c}$<smiles>CC(C(O)c1ccccc1)N(C)C(=O)CCN</smiles>

D, Lum, ref. 8b

Figure 1. Open-chain, chiral $\beta$-alanine derivatives.<smiles>C[C@H](C(O)c1ccccc1)N(C)/C(Cl)=C/N</smiles>

E, Myers, ref. 9<smiles></smiles>

G, McIntosh, ref. 11<smiles>CC(N=C(Cl)c1ccccc1)=C(Cl)C(C)(C)[C@@]1(C)CC2CCC(C)CC2O1</smiles>

F, Berkowitz, ref. 10<smiles>CC(c1ccccc1)N(/C(Cl)=C/CN([Al])C(=O)OCc1ccccc1)[C@@H](C)c1ccccc1</smiles>

H, this work

Figure 2. Chiral dianionic precursors for the enantioselective synthesis of $\alpha$ - and $\beta$-amino acids.

of chiral derivatives of $\beta$-aminopropionic acid such as $\mathbf{A}$ -

D (Figure 1) was explored ${ }^{8}$.

Motivated by the elegant work of Myers ${ }^{9}$, Berkowitz ${ }^{10}$, and $\mathrm{McIntosh}^{11}$, who have demonstrated the highly diastereoselective alkylation of chiral glycine-derived dianions E-G (Figure 2) en route to enantioenriched $\alpha$ amino acids, we decided to determine the diastereoselectivity of alkylation of chiral $\beta$-alanine-derived dianion H (Figure 2) ${ }^{12}$.

\section{Results and Discussion}

\section{A. Preparation of $(R, R)-N^{\prime}, N^{\prime}-B i s(\alpha-$ phenylethyl $)-N$ - carbobenzyloxypropionamide $[(R, R)-1]$.}

Chiral substrate $(R, R)-\mathbf{1}$ was obtained in $53 \%$ overall yield from $\beta$-alanine, following the synthetic route shown in Scheme 1. Protection of the amino group with benzyl chloroformate $(\mathrm{CbzCl})$ was followed by treatment with thionyl chloride to afford the corresponding acid chloride, which was added to $\operatorname{bis}[(R)-\alpha$-phenylethyl $]$ amine to give chiral amide $(R, R)-\mathbf{4}$, accompanied with varying amounts of chiral dipeptide $(R, R)-\mathbf{2}$.

\section{B. Stereoselectivity of C-alkylation of $(R, R)-1$}

$C$-Alkylation of chiral amide $(R, R)$-1 required employment of two equivalents of base (lithium diisopropylamide, LDA), owing to competitive $N$ metallation reaction (Scheme 2a). Furthermore, as Seebach has pointed out ${ }^{13}$, it is necessary to regenerate LDA from its conjugated acid since diisopropylamine does quench the reactive enolate (Scheme $2 b$ ). Therefore, only when dianion formation was followed by the addition of two equivalents of $n$-butyllithium in order to achieve lithiation of the produced diisopropylamine, was $C$-alkylation successfully accomplished (Scheme 2c).

Alternatively and more conveniently, efficient alkylation takes place when chiral amide $(R, R)-\mathbf{1}$ in THF solution is added at $-78^{\circ} \mathrm{C}$ to a THF solution of 2.2 equiv 


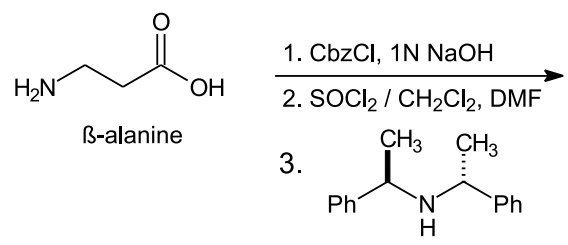<smiles>CC(c1ccccc1)N(C(=O)CCNC1CCCCC1)c1ccccc1</smiles>

$(R, R)-1,53 \%$ overall<smiles>CC(c1ccccc1)N(C(=O)CCN(C(=O)CCNC(=O)OCc1ccccc1)C(=O)OCc1ccccc1)C(C)c1ccccc1</smiles>

$(R, R)-2$

Scheme 1.

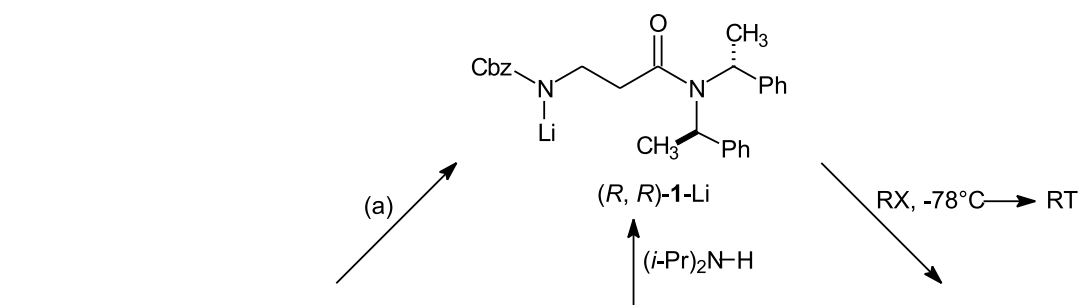<smiles>CC(c1ccccc1)N(C(=O)CCNC(=O)OCc1ccccc1)c1ccccc1</smiles>

$(R, R)-1$<smiles>CC(c1ccccc1)N(/C(Cl)=C/CN([Ge])[Tl])c1ccccc1</smiles>

$(R, R)-1-\mathrm{Li}_{2}$<smiles>[R]N(CCC(=O)N(C(C)c1ccccc1)[C@H](C)c1ccccc1)C1CCCCC1</smiles>

(N-alkylation)

(c)

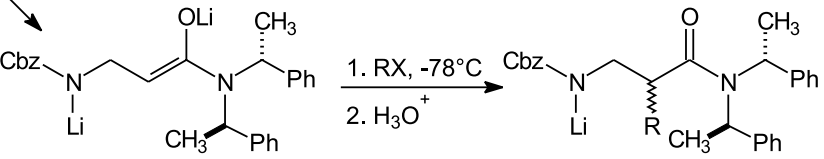

$(R, R)-1-\mathrm{Li}_{2}$

(C-alkylation)

(a) 1.1 equiv LDA / THF, $-78^{\circ} \mathrm{C}$. (b) 2.2 equiv LDA / THF, $-78^{\circ} \mathrm{C}$.

(c) 2.2 equiv LDA / THF followed by 2.2 equiv $n-\mathrm{BuLi},-78^{\circ} \mathrm{C}$.

Scheme 2 .

of $n$-BuLi; the resulting dianion was then treated with the electrophile still at $-78^{\circ} \mathrm{C}$. Results are summarized in Table 1.

In the absence of additives ${ }^{15}$, diastereoselectivities of alkylation varied in the range $67-82 \%$ (entries 1, 6, 11, and 14 in Table 1), with ethyl iodide leading to the highest $\mathrm{ds}=82 \%$. Reaction yields were only moderate. In contrast with alkylation reactions of chiral glycine derivatives containing the $\alpha$-phenylethyl auxiliary, which are greatly influenced by the presence of $\mathrm{LiCl}$ salt or HMPA (or DMPU) as co-solvent ${ }^{15}$, the diastereoselectivity of the alkylation reaction of chiral $\beta$-alanine derivative $(R, R)-\mathbf{1}$ $\mathrm{Li}_{2}$ is essentially unaffected by the incorporation of $\mathrm{LiCl}$ (entries 4, 5, 9, and 10 in Table 1) or the polar aprotic HMPA solvent. Nevertheless, reaction yields generally increased in the presence of the additive.

The absolute configuration of the newly created stereogenic center in the major diastereomeric product of methylation of $(R, R)-\mathbf{1}-\mathrm{Li}_{2}$ was ascertained by hydrogenolytic removal of the $\mathrm{N}$-Cbz protecting group, followed by acid hydrolysis to the known $\beta$-amino acid (S)- $\alpha$-methyl- $\beta$-alanine, $(S)$-7 (Scheme 3).

Although we were unable to separate the diastereomeric products $(R, R, S)-\mathbf{3}$ and $(R, R, R)-\mathbf{3}$, chemical correlation of the major diastereoisomer $(\mathrm{dr}=75: 25)$ with $(S)$ - $\alpha$-methyl$\beta$-alanine ${ }^{18}$ was unequivocal (Scheme 3 ). 
Table 1. Diastereoselectivity of dianion $(R, R)-\mathbf{1}-\mathrm{Li}_{2}$ alkylations<smiles>CC(c1ccccc1)N(C(=O)CCNC(=O)OCc1ccccc1)c1ccccc1</smiles>

$(R, R)-1$

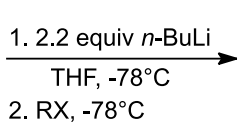

2. $\mathrm{RX},-78^{\circ} \mathrm{C}$<smiles>[R]C(CNC(=O)N1CCCCC1)C(=O)N(C(C)c1ccccc1)[C@@H](C)c1ccccc1</smiles>

$3-6$

\begin{tabular}{|c|c|c|c|c|}
\hline Entry & RX & $\begin{array}{c}\text { Additive } \\
\text { (equiv) }\end{array}$ & $\mathrm{dr}^{\mathrm{a}}$ & $\begin{array}{c}\text { Yield } \\
(\%)\end{array}$ \\
\hline 1 & $\mathrm{CH}_{3} \mathrm{I}$ & - & $73: 27$ & 60 \\
\hline 2 & $\mathrm{CH}_{3}^{3} \mathrm{I}$ & $\mathrm{HMPA}^{\mathrm{b}}(1.0)$ & $74: 26$ & 75 \\
\hline 3 & $\mathrm{CH}_{3}^{3} \mathrm{I}$ & HMPA (3.0) & $72: 28$ & 81 \\
\hline 4 & $\mathrm{CH}_{3}^{3} \mathrm{I}$ & $\mathrm{LiCl}(1.0)$ & $75: 25$ & 41 \\
\hline 5 & $\mathrm{CH}_{3} \mathrm{I}$ & $\mathrm{LiCl}(3.0)$ & $75: 25$ & 80 \\
\hline 6 & $\mathrm{PhCH}_{2} \mathrm{Br}$ & - & $67: 33$ & 51 \\
\hline 7 & $\mathrm{PhCH}_{2}^{2} \mathrm{Br}$ & HMPA (1.0) & $72: 28$ & 80 \\
\hline 8 & $\mathrm{PhCH}_{2}^{2} \mathrm{Br}$ & HMPA (3.0) & $86: 14$ & 73 \\
\hline 9 & $\mathrm{PhCH}_{2}^{2} \mathrm{Br}$ & $\mathrm{LiCl}(1.0)$ & $65: 35$ & 85 \\
\hline 10 & $\mathrm{PhCH}_{2} \mathrm{Br}$ & $\mathrm{LiCl}(3.0)$ & $66: 34$ & 83 \\
\hline 11 & EtI & - & $82: 18$ & 62 \\
\hline 12 & EtI & HMPA (1.0) & $78: 22$ & 42 \\
\hline 13 & EtI & HMPA (3.0) & $75: 25$ & 32 \\
\hline 14 & $n$-PrI & - & $72: 28$ & 24 \\
\hline 15 & $n$-PrI & HMPA (1.0) & $71: 29$ & 50 \\
\hline 16 & $n$-PrI & HMPA (3.0) & $72: 28$ & 67 \\
\hline
\end{tabular}

${ }^{a}$ Diastereomeric ratio, after flash chromatography. ${ }^{14}$ The diastereomeric mixture proved inseparable in our hands. ${ }^{b}$ Hexamethylphosphoramide.

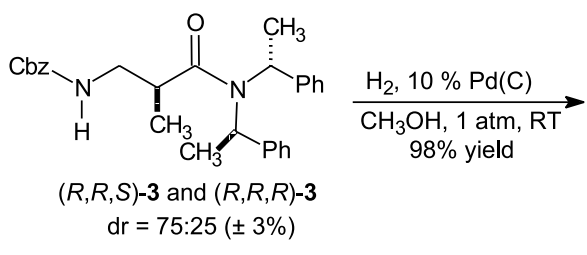
$\mathrm{dr}=75: 25( \pm 3 \%)$<smiles>CC(c1ccccc1)N(C(=O)[C@H](C)CN)C(C)c1ccccc1</smiles><smiles>CC(CN)C(=O)O</smiles>

(S)-7, 93\% yield $44-56 \%$ ee

Scheme 3.

\section{Molecular Modelling.}

In order to rationalize the observed stereoinduction by the chiral bis( $\alpha$-phenylethyl)amino auxiliary in dianion $(R, R)-\mathbf{1}-\mathrm{Li}_{2}$, we resorted to molecular modeling studies by means of semiempirical PM3 ${ }^{19}$ and $a b$ initio calculations ${ }^{20}$.

First of all, a search for low-energy conformations of starting chiral amide $(R, R)-\mathbf{1}$ was undertook at semiempirical PM3 level, by means of the PC Spartan-Pro $\operatorname{program}^{19}$, which makes use of Monte Carlo stocastic methods $^{21}$. This conformational search afforded nine structures corresponding to local minima within a
$10 \mathrm{kcal} / \mathrm{mol}$ maximum energy threshold. These nine lowenergy conformers were used as starting geometries for optimization at ab initio HF/3-21G and B3LYP/3-21+G(d) levels of theory. All studies converged into a global energy minimum, I, shown in Figure 3.

Salient features of structure $\mathbf{I}$ are (1) the $\mathrm{N}-\mathrm{H}-\mathrm{O}$ hydrogen bond stabilizing a "folded" conformation of the $\beta$-aminopropionic segment, and (2) a $\pi-\pi$ attractive interaction ${ }^{23}$ between the aromatic rings, which is evidently able to overcome the anticipated preference for conformation $\mathbf{J}$, where the concept of allylic $\mathrm{A}^{1,3} \operatorname{strain}^{22}$ is fulfilled. 
A "folded" conformation in the $\beta$-aminopropionic segment of monoanion $(R, R)-\mathbf{1}-\mathrm{Li}$ is even more strongly favored (Figure 4). Indeed, structure $\mathbf{K}$ presenting a sixmembered chelate $\mathrm{N}-\mathrm{Li}-\mathrm{O}$ is estimated to be $22.3 \mathrm{kcal} /$ mol more stable than an "extended" conformer $\mathbf{L}$ (Figure 4). Conformer $\mathbf{K}$ is also stabilized by $\pi-\pi$ attraction ${ }^{23}$.

Finally, dianion $(R, R)-\mathbf{1}-\mathrm{Li}_{2}$ presents the lowest-energy structure $\mathbf{M}$ depicted in Figure 5. Most interesting, the ion triplet $^{24}$ configuration of the dilithium salt $\mathbf{M}$ is estimated to be a remarkable $33.8 \mathrm{kcal} / \mathrm{mol}$ lower in energy than enolate N (Figure 5).

From observation of the calculated lowest-energy conformation for $(R, R)-\mathbf{1}-\mathrm{Li}_{2}$ it can be appreciated that enolate face $S i$ is less hindered towards electrophilic approach (syn to methyl vis-a-vis phenyl groups on the $\alpha$ phenethyl moieties) relative to the $R e$ face, which is syn to the phenyl rings. Indeed, predicted addition of the electrophile on the $S i$ face should lead to the preferred
I:<smiles>CC(c1ccccc1)[C@H](C)N(C(=O)CCN1CCOC(=O)CO1)c1ccccc1</smiles>

( $\pi-\pi$ attraction and H-bond)

$\mathbf{J}:$<smiles></smiles>
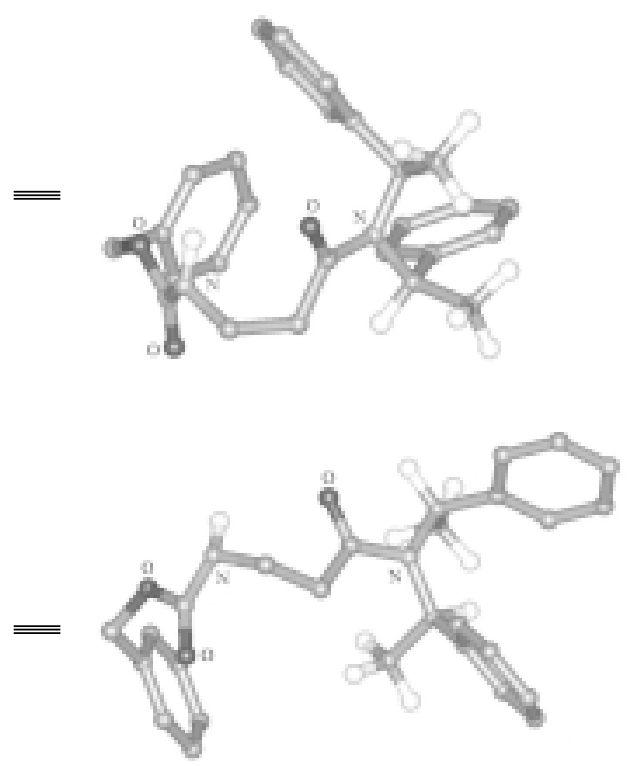

Figure 3. Ab initio HF/3-21G conformation of minimun energy for $(R, R)-\mathbf{1}(\mathbf{I})$. An alternative conformation $\mathbf{J}$ fulfilling anticipation based on the concept of allylic $\mathrm{A}^{1,3} \operatorname{strain}^{22}$ is calculated as $6.7 \mathrm{kcal} / \mathrm{mol}$ higher in energy.

$\mathbf{K}:$

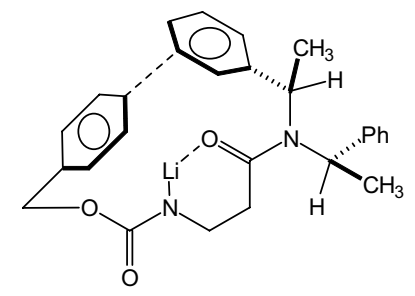

$(\pi-\pi$ attraction and $\mathrm{N}-\mathrm{Li}---\mathrm{O}$ bond $)$

L:

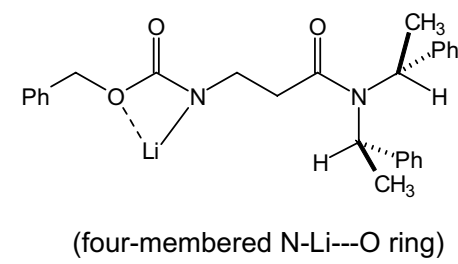
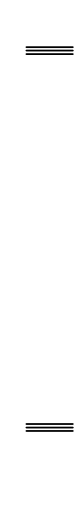
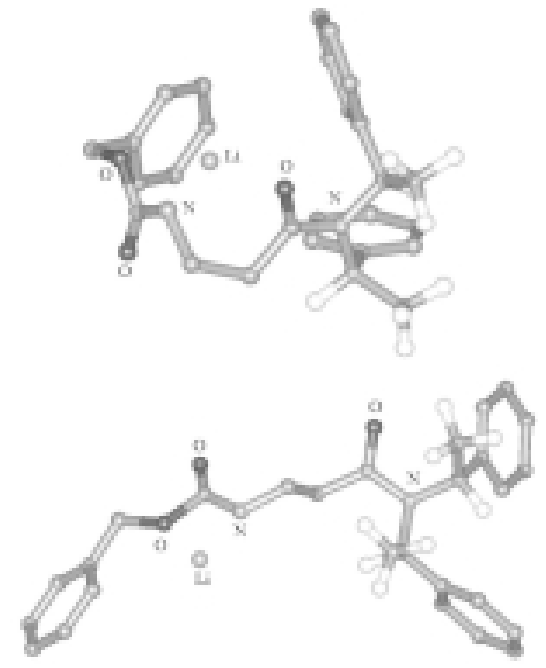

Figure 4. $\mathrm{A} b$ initio $\mathrm{HF} / 3-21 \mathrm{G}$ conformation of minimun energy for $(R, R)-\mathbf{1}-\mathrm{Li}(\mathbf{K})$. Alternative conformation $\mathbf{L}$, presenting a four-membered $\mathrm{N}-\mathrm{Li}-\mathrm{O}$ chelate, calculated to be $22.3 \mathrm{kcal} / \mathrm{mol}$ higher in energy. 
M:
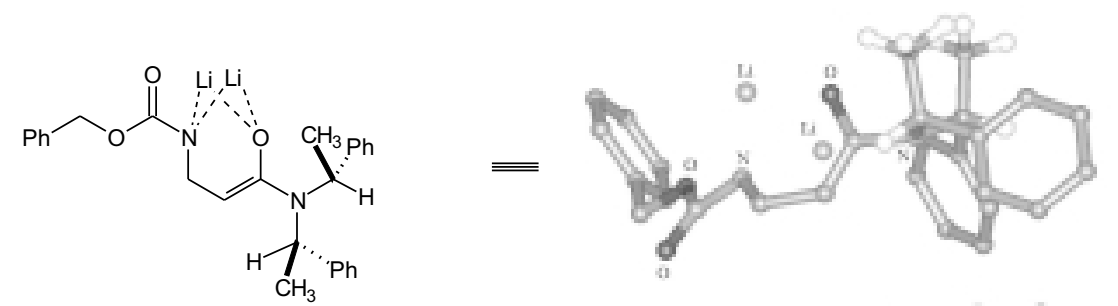

N:
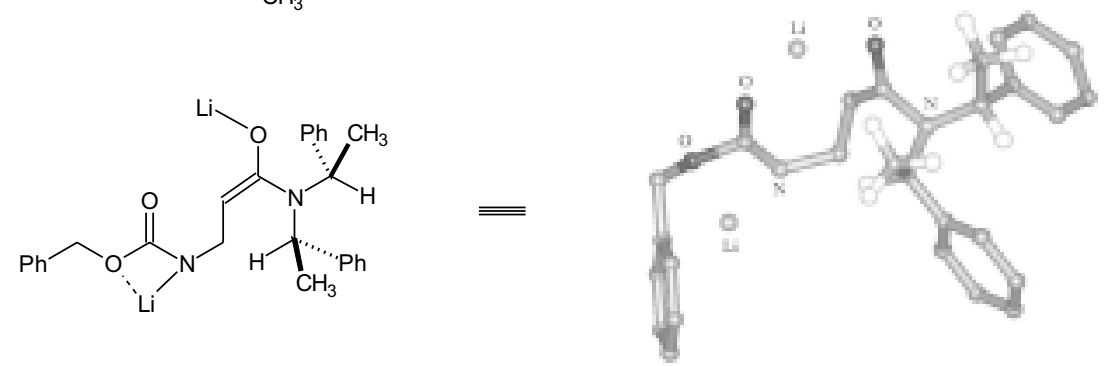

Figure 5. Ab initio $\mathrm{HF} / 3-21 \mathrm{G}$ conformation of minimun energy for $(R, R)-\mathbf{1}-\mathrm{Li}_{2}(\mathbf{M})$, presenting an ion triplet ${ }^{24}$ configuration. Alternative $E$-enolate $\mathbf{N}$ is calculated as $33.8 \mathrm{kcal} / \mathrm{mol}$ higher in energy.

formation of the $(S)$-configurated stereogenic center, as experimentally observed (Scheme 3 ).

\section{Conclusions}

$C$-Alkylation of $(R, R)$-1, a chiral $\beta$-alanine derivative containing the bis $(\alpha$-phenylethyl)amine moiety, was accomplished in moderate to good yields via dianion $(R, R)-\mathbf{1}-\mathrm{Li}_{2}$. Observed diastereoselectivities with various alkyl halides varied in the $65-86 \%$ ds range, and were essentially unaffected by the presence of additives $(\mathrm{LiCl}$, HMPA).

Assignment of configuration at the newly created stereogenic center in the methylation reaction was achieved by chemical correlation with $(S)-\alpha$-methyl- $\beta$-alanine. This configuration for the main product of alkylation can be rationalized in terms of the presumed conformation of minimum energy for $(R, R)-\mathbf{1}-\mathrm{Li}_{2}$, determined by ab initio HF/3-21G calculations, which exhibits a relatively unhindered $S i$ face of the enolate.

\section{Experimental Section}

\section{Materials and Methods}

Flasks, stirring bars, and hypodermic needles used for the generation and reactions of organolithiums were dried for ca. $12 \mathrm{~h}$ at $120^{\circ} \mathrm{C}$ and allowed to cool in a desiccator over anhydrous $\mathrm{CaSO}_{4}$. Anhydrous solvents were obtained by distillation from benzophenone ketyl ${ }^{25}$. The $n$ - butyllithium employed was titrated according to the method of Juaristi, et $\mathrm{al}^{26}$.

TLC: Merck-DC-F ${ }_{254}$ plates, detection by UV light. Flash column chromatography ${ }^{14}$ : Merck silica gel (0.040$0.063 \mathrm{~mm})$. Melting points: Mel Temp apparatus, not corrected. ${ }^{1} \mathrm{H}$ NMR spectra: Jeol Eclipse-400 (400 MHz), Bruker Ultra Shield (300 MHz), and Jeol GSX-270 (270 $\mathrm{MHz}$ ) spectrometers. ${ }^{13} \mathrm{C}$ NMR spectra: Jeol Eclipse-400 (100 MHz), Bruker Ultra Shield (75 MHz), and Jeol GSX$270(67.5 \mathrm{MHz})$. Chemical shifts $(\delta)$ in ppm downfield from internal TMS reference; the coupling constants $(J)$ are given in hertz. High-resolution mass spectra (HRMS) were obtained at Instituto de Química, UNAM, México.

\section{Procedures}

$(R, R)-N$ ',N'-Bis( I'-phenylethyl)-N-carbobenzyloxypropionamide $[(R, R)-1]$

A solution containing $10.0 \mathrm{~g}(112.0 \mathrm{mmol})$ of $\beta$ aminopropionic acid in $112.0 \mathrm{~mL}$ of $1 \mathrm{~N} \mathrm{NaOH}$ was cooled in an ice bath and treated with $17.6 \mathrm{~mL}(21.0 \mathrm{~g}, 0.12 \mathrm{~mol})$ of benzylchloroformate, followed by slow addition of 112.0 $\mathrm{mL}$ of $1 \mathrm{~N} \mathrm{NaOH}$. The resulting mixture was allowed to warm up to ambient temperature and stirred overnight. The crude product was extracted with three $100 \mathrm{~mL}$ portions of diethyl ether, and the aqueous phase was acidified with $6 \mathrm{~N}$ $\mathrm{HCl}$ to $\mathrm{pH}<4.0$. The precipitate that developed was dissolved in $\mathrm{CH}_{2} \mathrm{Cl}_{2}$, dried over anhydrous $\mathrm{Na}_{2} \mathrm{SO}_{4}$ and concentrated in the rotary evaporator. Recrystallization of the resulting 
residue from ethyl acetate:ethanol (10:1) afforded $21.5 \mathrm{~g}$ ( $86 \%$ yield) of the desired product ( $N$-carbobenzyloxy-3aminopropionic acid), mp $103-104^{\circ} \mathrm{C}$ (lit. ${ }^{27 \mathrm{a}} \mathrm{mp} 103-105^{\circ} \mathrm{C}$ ). This crystalline material $(0.5 \mathrm{~g}, 2.2 \mathrm{mmol})$ was dissolved in $6.0 \mathrm{~mL}$ of $\mathrm{CH}_{2} \mathrm{Cl}_{2}$ and three drops of dimethylformamide. The resulting solution was treated with $0.65 \mathrm{~mL}(9.0 \mathrm{mmol})$ of thionyl chloride, and heated to reflux for $4 \mathrm{~h}$. The solvent was removed in the rotary evaporator and the residue was washed three times with toluene, and then was redissolved in $4.0 \mathrm{~mL}$ of $\mathrm{CH}_{2} \mathrm{Cl}_{2}$, and added to a solution of $1.0 \mathrm{~g}(4.4$ mmol) of $(R, R)-N, N$-bis-(1-phenylethyl)amine ${ }^{27 \mathrm{~b}}$ in $4.0 \mathrm{~mL}$ of toluene, under nitrogen at $0^{\circ} \mathrm{C}$. The reaction mixture was allowed to warm up and stirred at ambient temperature for $14 \mathrm{~h}$. The solvent was removed in the rotary evaporator and the product was redissolved in diehtyl ether, dried over anhydrous $\mathrm{Na}_{2} \mathrm{SO}_{4}$ filtered, and concentrated to give an oil that was purified by flash chromatography (hexane:EtOAc, $9: 1 \rightarrow 7: 3)$ to afford $0.60 \mathrm{~g}(62 \%$ yield $)$ of $(R, R)-1,[\alpha]^{28}{ }_{\mathrm{D}}=$ $+111.5\left(\mathrm{c}=1, \mathrm{CHCl}_{3}\right) .{ }^{1} \mathrm{H}-\mathrm{NMR}$ (DMSO- $d_{6}, 300 \mathrm{MHz}$, $\left.100^{\circ} \mathrm{C}\right)^{28} \delta 1.70(\mathrm{~d}, J 7.1,3 \mathrm{H}), 1.71(\mathrm{~d}, J 7.1 .3 \mathrm{H}), 2.35-2.46$ (m, 1H), 2.57-2.68 (m, 1H), 3.26-3.37 (br, 2H), $5.06(\sim \mathrm{s}$, $2 \mathrm{H}), 5.13$ (q, J 7.1, 2H), 6.55-6.63 (br, 1H), 7.10-7.23 (m, $10 \mathrm{H}), 7.27-7.42(\mathrm{~m}, 5 \mathrm{H}) .{ }^{13} \mathrm{C}-\mathrm{NMR}$ (DMSO- $d_{6} .75 \mathrm{MHz}$, $\left.100^{\circ} \mathrm{C}\right) \delta 19.5,36.2,38.4,54.0,66.3,127.5,128.1,128.3$, 128.4, 128.6, 129.1, 138.2, 142.3, 156.8, 171.5. HRMS calcd for $\mathrm{C}_{27} \mathrm{H}_{30} \mathrm{~N}_{2} \mathrm{O}_{3}\left(\mathrm{M}^{+}+1\right)$ : 431.2335 . Found: 431.2354 .

$(R, R)-N$, $N$ '-Bis( I'-phenylethyl $)-N$-(N"'-carbobenzyloxyaminopropionyl) $N$-carbobenzyl-oxypropionamide [(R,R)-2]

This dipeptide was obtained as side product in the preparation of $(R, R)-1 .[\alpha]_{\mathrm{D}}^{28}=+82.6\left(\mathrm{c}=1, \mathrm{CHCl}_{3}\right) .{ }^{1} \mathrm{H}-$ NMR (DMSO- $\left.d_{6}, 400 \mathrm{MHz}, 100^{\circ} \mathrm{C}\right) \delta 1.65(\mathrm{~d}, J 7.3,6 \mathrm{H})$, $2.46\left(\mathrm{ddd},{ }^{1} J 15.5,{ }^{2} J 7.7,{ }^{3} J 7.6,1 \mathrm{H}\right), 2.64\left(\mathrm{ddd},{ }^{1} J 15.5\right.$, ${ }^{2} J$ 7.6, ${ }^{3} J$ 7.6, 1H), $3.03(\mathrm{t}, J 6.8,2 \mathrm{H}), 3.35\left(\mathrm{dt},{ }^{1} J 6.6\right.$, $\left.{ }^{2} J 6.6,2 \mathrm{H}\right), 3.94\left(\mathrm{dd},{ }^{1} \mathrm{~J} 7.5,{ }^{2} J 7.5,2 \mathrm{H}\right), 5.01-5.18(\mathrm{~m}, 4 \mathrm{H})$, $5.21(\mathrm{~d}, J 12.5,1 \mathrm{H}), 5.25(\mathrm{~d}, J 12.5,1 \mathrm{H}), 6.78(\mathrm{br}, 1 \mathrm{H})$, 7.06-7.55 (m, 20H). ${ }^{13} \mathrm{C}-\mathrm{NMR}$ (DMSO- $d_{6}, 100 \mathrm{MHz}$, $\left.100^{\circ} \mathrm{C}\right) \delta 19.0,34.4,37.4,38.6,41.5,53.5,53.5,65.9,68.6$, $127.1,127.8,128.0,128.1,128.2,128.2,128.4,128.7$, $128.9,136.0,137.8,141.8,154.3,156.5,170.4,173.8 \mathrm{MS}$ $(15 \mathrm{eV}) \mathrm{m} / \mathrm{z} 636\left(\mathrm{M}^{+}+1\right), 530,422,303,259,210,120$, 91. HRMS calcd for $\mathrm{C}_{38} \mathrm{H}_{42} \mathrm{~N}_{3} \mathrm{O}_{6}:$ 636.3074. Found: 636.3084 .

General procedure for the reaction of $\beta$-alaninamide dianion $(R, R)-1-L i_{2}$ with electrophiles

To a solution of $0.43 \mathrm{~mL}(1.02 \mathrm{mmol})$ of $2.6 \mathrm{~N} n$-BuLi in $5 \mathrm{~mL}$ of $\mathrm{THF}$ at $-78^{\circ} \mathrm{C}$ and under nitrogen atmosphere was added dropwise $0.20 \mathrm{~g}(0.46 \mathrm{mmol})$ of $(R, R)-1$ in 10 $\mathrm{mL}$ of THF. The resulting solution was stirred for $1 \mathrm{~h}$ at $-78^{\circ} \mathrm{C}$ and then the alkylating agent (1.1 equiv) was added with continuous stirring. The reaction mixture was stirred at $-78^{\circ} \mathrm{C}$ for $3-4 \mathrm{~h}$ before quenching with aq. $\mathrm{NH}_{4} \mathrm{Cl}$. The product was extracted with three 5-mL portions of EtOAc, the combined organic extracts were dried over anhydrous $\mathrm{Na}_{2} \mathrm{SO}_{4}$, filtered and concentrated. Final purification of the diastereomeric mixture of products was accomplished by flash chromatography ${ }^{14}$ (hexane:EtOAc, 80:20).

(R,R)-N',N'-Bis(1'-phenylethyl)-N-carbobenzyloxy-(2S)-2methylpropionamide $[(R, R, S)-3]$.

These NMR data correspond to the major product of methylation, as extracted from spectra of the unseparable diastereomeric mixture (see section $\mathrm{B}$ and Table 1 ). ${ }^{1} \mathrm{H}-$ NMR (DMSO- $\left.d_{6}, 300 \mathrm{MHz}, 100^{\circ} \mathrm{C}^{28}\right) \delta 0.72(\mathrm{~d}, J 6.6,3 \mathrm{H})$, 1.69 (d, J 6.6 Hz, 3H), 1.71 (d, J 6.0, 3H), 2.83-2.97 (m, $1 \mathrm{H}), 3.00-3.13(\mathrm{~m}, 1 \mathrm{H}), 3.24-3.36(\mathrm{~m}, 1 \mathrm{H}), 5.08(\mathrm{~s}, 2 \mathrm{H})$, 5.12-5.32 (br, 2H), 6.67-6.80 (br, 1H), 7.05-7.40 (m, 15H). ${ }^{13} \mathrm{C}-\mathrm{NMR}\left(\mathrm{DMSO}-d_{6}, 75 \mathrm{MHz}, 100^{\circ} \mathrm{C}\right) \delta 14.0,18.3,37.4$, 44.2, 52.0, 64.9, 126.1, 126.7, 126.9, 127.0, 127.2, 127.6, 136.7, 141.0, 155.7, 174.4.HRMS calcd for $\mathrm{C}_{28} \mathrm{H}_{32} \mathrm{~N}_{2} \mathrm{O}_{3}$ : 445.2491. Found: 445.2492.

(R,R)-N',N'-Bis(1'-phenylethyl)-N-carbobenzyloxy-(2S)-2benzylpropionamide $[(R, R, S)-4]$.

The following NMR data correspond to the major product of benzylation, which was separated and purified by fractional crystallization from EtOAc, mp $187-189^{\circ} \mathrm{C}$. $[\alpha]^{28}=+89.6\left(\mathrm{c}=1, \mathrm{CHCl}_{3}\right)$. It is assumed that benzylation takes place with similar stereochemical outcome as the methylation reaction. ${ }^{1} \mathrm{H}-\mathrm{NMR}$ (DMSO- $d_{6}, 300 \mathrm{MHz}$, $\left.100^{\circ} \mathrm{C}\right) \delta 1.33(\mathrm{br}, 3 \mathrm{H}), 1.54(\mathrm{br}, 3 \mathrm{H}), 2.7(\mathrm{~d}, J 6.5,2 \mathrm{H})$, 3.19 (m, 1H), 3.27-3.42 (m, 2H), 4.83 (br, 1H), 5.07 (m, 2H), 6.76 (br, 1H), 6.98-7.35 (m, 20H). ${ }^{13} \mathrm{C}-\mathrm{NMR}$ (DMSO$\left.d_{6}, 75 \mathrm{MHz}, 100^{\circ} \mathrm{C}\right) \delta 17.9,35.9,43.2,44.5,53.1,65.0$, $125.4,127.0,127.0,127.5,127.6,128.5,136.6,138.8$, 139.9, 141.2, 155.7, 172.7. HRMS calcd for $\mathrm{C}_{34} \mathrm{H}_{37} \mathrm{~N}_{2} \mathrm{O}_{3}$ $\left(\mathrm{M}^{+}+1\right)$ : 521.2804. Found: 521.2797

(R,R)-N',N'-Bis(1'-phenylethyl)-N-carbobenzyloxy-(2S)ethylpropionamide $[(R, R, S)-5]$.

The following NMR data correspond to the major product of alkylation with ethyl iodide, as extracted from spectra of the unseparable diastereomeric mixture (see section B and Table 1), and assuming that ethylation takes place with the same stereochemical outcome as the methylation reaction. 
${ }^{1} \mathrm{H}-\mathrm{NMR}$ (DMSO- $\left.d_{6}, 300 \mathrm{MHz}, 100^{\circ} \mathrm{C}\right) \delta 0.63(\mathrm{t}, J 7.4 \mathrm{~Hz}$, $3 \mathrm{H}), 1.24-1.43(\mathrm{~m}, 2 \mathrm{H}), 1.67(\mathrm{~d}, J 7.0 \mathrm{~Hz}, 6 \mathrm{H}), 2.91(\mathrm{~m}$, 1H), 3.14 (ddd, ${ }^{1} J 13.4 \mathrm{~Hz},{ }^{2} J 6.3 \mathrm{~Hz},{ }^{3} J 2.0 \mathrm{~Hz}, 1 \mathrm{H}$ ), 3.32 (ddd, $\left.{ }^{1} \mathrm{~J} 13.2 \mathrm{~Hz},{ }^{2} J 6.5 \mathrm{~Hz},{ }^{3} \mathrm{~J} 2.2 \mathrm{~Hz}, 1 \mathrm{H}\right), 5.05$ (s, 2H), 5.14 (q, J7.0 Hz, 2H), $6.62(\mathrm{br}, 1 \mathrm{H}), 7.10(\mathrm{~m}, 10 \mathrm{H}) 7.32(\mathrm{~m}, 5 \mathrm{H})$. ${ }^{13} \mathrm{C}-\mathrm{NMR}$ (DMSO- $\left.d_{6}, 75 \mathrm{MHz}, 100^{\circ} \mathrm{C}\right) \delta 10.3,18.1,22.6$, 42.7, 43.6, 52.5, 65.0, 126.0, 126.8, 126.9, 127.0, 127.1, 127.6, 136.7, 141.0, 155.7, 173.5. HRMS calcd for $\mathrm{C}_{29} \mathrm{H}_{35} \mathrm{~N}_{2} \mathrm{O}_{3}\left(\mathrm{M}^{+}+1\right)$ : 459.2648. Found: 459.2661.

$(R, R)-N^{\prime}, N$ '-Bis (1'-phenylethyl)-N-carbobenzyloxy-(2S)(n-propyl)propionamide $[(R, R, S)-6]$.

The following NMR data correspond to the major product of alkylation with $n$-propyl iodide, as extracted from spectra of the unseparable diastereomeric mixture (see section B and Table 1), and assuming that propylation takes place with the same stereochemical outcome as the methylation reaction. ${ }^{1} \mathrm{H}-\mathrm{NMR}$ (DMSO- $d_{6}, 300 \mathrm{MHz}$, $\left.100^{\circ} \mathrm{C}\right) \delta 0.71(\mathrm{t}, J 7.2 \mathrm{~Hz}, 3 \mathrm{H}), 0.94-1.14(\mathrm{~m}, 2 \mathrm{H}), 1.25-$ $1.35(\mathrm{~m}, 2 \mathrm{H}), 1.66(\mathrm{~d}, J 7.0 \mathrm{~Hz}, 6 \mathrm{H}), 2.90-3.00(\mathrm{~m}, 1 \mathrm{H})$, 3.08-3.19 (m, 1H), 3.31 (ddd, ${ }^{1} J 13.2 \mathrm{~Hz},{ }^{2} J 6.5 \mathrm{~Hz},{ }^{3} \mathrm{~J} 2.1$ $\mathrm{Hz}, 1 \mathrm{H}), 5.04$ (s, 2H), 5.12 (q, J 7.0, 2H), 6.61 (br, 1H), $7.05(\mathrm{~m}, 10 \mathrm{H}) 7.28(\mathrm{~m}, 5 \mathrm{H}) .{ }^{13} \mathrm{C}-\mathrm{NMR}$ (DMSO- $d_{6}, 75 \mathrm{MHz}$, $\left.100^{\circ} \mathrm{C}\right) \delta 13.3,18.1,18.9,31.9,42.1,42.8,52.6,65.0$, 126.0, 126.7, 126.8, 126.9, 127.0, 127.1, 127.6, 136.7, 140.7, 155.6, 173.6. HRMS calcd for $\mathrm{C}_{30} \mathrm{H}_{37} \mathrm{~N}_{2} \mathrm{O}_{3}\left(\mathrm{M}^{+}+\right.$ 1): 473.2804. Found: 473.2794.

\section{(S)-2-Methyl-3-aminopropionic acid [(S)-7]}

In a hydrogenation flask was placed $0.34 \mathrm{~g}(0.77 \mathrm{mmol})$ of the diastereomeric mixture of $(R, R, S)-\mathbf{3}$ and $(R, R, R)-\mathbf{3}$ $(\mathrm{dr}=75: 25), 0.035 \mathrm{~g}$ of $10 \% \mathrm{Pd}(\mathrm{C})$, and $25 \mathrm{~mL}$ of methanol. The flask was pressurized to 1 atm of $\mathrm{H}_{2}$ and stirred at ambient temperature for $6 \mathrm{~h}$. The reaction mixture was filtered over celite and concentrated in a rotary evaporator to afford the deprotected amine in $98 \%$ yield $(0.23 \mathrm{~g})$. This product was transferred to a glass ampoule and dissolved in $8.0 \mathrm{~mL}$ of $4 \mathrm{~N} \mathrm{HCl}$ and heated to $90^{\circ} \mathrm{C}$ for $14 \mathrm{~h}$. The crude product was washed with three $20-\mathrm{mL}$ portions of $\mathrm{CH}_{2} \mathrm{Cl}_{2}$, the aqueous phase was concentrated, and the residue was adsorbed to acidic ion exchange resin Dowex 50W X4. The residue was washed with distilled water until the washings came out neutral, and then the free amino acid was recovered with $0.1 \mathrm{~N}$ aqueous $\mathrm{NH}_{4} \mathrm{OH}$. Evaporation afforded $0.07 \mathrm{~g}$ (93\% yield) of the chiral $\beta$ amino acid $(S)-7$ (expected ee $=50 \%$, based on the $75: 25$ diastereomeric ratio of the starting material $(R, R, S)$ - and $(R, R, R)-3) \cdot[\alpha]^{28}{ }_{\mathrm{D}}=+7.9(\mathrm{c}=1.03,1 \mathrm{~N} \mathrm{HCl})$, lit. $^{29}[\alpha]_{\mathrm{D}}^{28}=$ - $14.2\left(\mathrm{c}=0.42, \mathrm{H}_{2} \mathrm{O}\right)$ for the pure $(R)$ enantiomer.

\section{Acknowledgments}

We are indebted to Conacyt-Mexico for financial support via grant L0006-E9607. We are also grateful to Víctor M. González and María Luisa Rodríguez for their assistance in the recording of NMR spectra.

\section{References}

1. See, for example: Ojima, I.; Lin, S.N.; Wang, T. Curr. Med. Chem. 1999, 6, 927.

2. See, for example: Bates, R.B.; Brusoe, K.G. Burns, J.J.; Caldera, S.; Cui, W.; Gangwar S.; Gramme, M.R.; McClure, K.J.; Rouen, G.P.; Shadow, H.; Stessman, C.C.; Taylor, S.R.; Vu, V.H.; Yarick, G.V. Zhang, J.X.; Pettit, G.R.; Bontems, R. J. Am. Chem. Soc. 1997, 119, 2111.

3. For example, $(R)-\beta$-dopa in mushrooms; see: von Nussbaum, F.; Spiteller, P.; Ruth, M. Steglich, W.; Wanner, G.; Gamblin, B.; Stievano, L.; Wagner, F.E. Angew. Chem. Int. Ed., 1998, 37, 3292.

4. See, for example: Tamariz, J. In Enantioselective Synthesis of $\beta$-Amino Acids; Juaristi, E., Ed.; Wiley: New York, 1997; pp 45-66.

5. See, for example: Georg, G. I., Ed., The Organic Chemistry of $\beta$-Lactams; Verlag Chemie: New York, 1993.

6. See, for example: (a) Seebach, D.; Gademann, K.; Ernst, M.; Hoyer, D. Angew. Chem. Int. Ed. 1999, 38, 1223. (b) Gellman, S.H. Acc. Chem. Res. 1998, 31, 173.

7. (a) Juaristi, E.; Quintana, D.; Escalante, J. Aldrichim. Acta 1994, 27, 3. (b) Cole, D.C. Tetrahedron 1994, 50, 9517. (c) Cardillo, G.; Tomasini, C. Chem. Soc. Rev. 1996, 23, 117. (d) Juaristi, E., Ed. Enantioselective Synthesis of $\beta$-Amino Acids; Wiley: New York, 1997. (e) Juaristi, E.; López-Ruiz, H. Curr. Med. Chem. 1999, 6, 983.

8. (a) Ponsinet, R.; Chassaing, G.; Vaissermann J.; Lavielle, S. Eur. J. Org. Chem. 2000, 83. (b) Nagula, G.; Huber, V.J.; Lum, C.; Goodman, B.A. Org. Lett. 2000, 2, 3527. (c) Gutiérrez-García, V.M.; LópezRuiz, H. Reyes-Rangel, G.; Juaristi, E. Tetrahedron 2001, 57, 6487.

9. (a) Myers, A.G.; Gleason, J.L.; Yoon, T. J. Am. Chem. Soc. 1995, 117, 8488. (b) Myers, A.G.; Gleason, J.L.; Yoon, T.; Kung, D.W. J. Am. Chem. Soc. 1997, 119, 656. (c) Myers, A.G.; Schnider, P.; Kwoon S.; Kung, D.W. J. Org. Chem. 1999, 64, 3322.

10. Berkowitz, D.B.; Smith, M.K. J. Org. Chem. 1995, $60,1233$. 
11. McIntosh, J.M.; Peters, S. Synthesis 1999, 635.

12. See, also: (a) Seebach, D.; Estermann, H. Tetrahedron Lett. 1987, 28, 3103. (b) Seebach, D.; Jacobi, A.; Rueping, M.; Gademann, K.; Ernst, M.; Jaun, B. Helv. Chim. Acta 2000, 83, 2115. (c) Papa, C.; Tomasini, C. Eur. J. Org. Chem. 2000, 1569. (d) Beatty, M.; Jennings-White, C.; Avery, M.A. J. Chem. Soc., Perkin Trans. 1 1992, 1637.

13. Seebach, D.; Imwinkelried, R.; Weber, T. In Modern Synthetic Methods 1986, Scheffold, R., Ed.; Springer Verlag: Berlin, 1986; pp 125-259 and refs. 77-79 therein.

14. Still, W.C.; Kahn, M.; Mitra, A. J. Org. Chem. 1978, 43, 2923.

15. Reaction additives such as "inert" inorganic salts $(\mathrm{LiCl}$, $\mathrm{LiClO}_{4}$, etc.) and polar aprotic cosolvents (HMPA, DMPU, ${ }^{16}$ etc.) can have a profound effect on the diastereoselectivity of chiral enolate alkylation. See, for example: (a) Juaristi, E.; León-Romo, J.L.; RamírezQuirós, Y. J. Org. Chem. 1999, 64, 2914. (b) Reyes, A.; Juaristi, E. Tetrahedron: Asymmetry 2000, 11, 1411.

16. DMPU, $N, N$-dimethylpropylene urea. For leading references on the use of DMPU, see: (a) Seebach, D.; Beck, K.A.; Studer, A. Modern Synthetic Methods 1995; VCH Publishers: Basel, 1995; pp 1-178. (b) Juaristi, E.; Murer, P.; Seebach, D. Synthesis 1993, 1243. (c) Mukhopadhyay, T.; Seebach, D. Helv. Chim. Acta 1982, 65, 385.

17. For excellent reviews on salt effects in chemical reactivity, see ref. 16a and also: Loupy, A. Tchoubar, B.; Astruc, D. Chem. Rev. 1992, 92, 1141.

18. Juaristi, E.; Quintana, D.; Balderas, M.; García-Pérez, E. Tetrahedron: Asymmetry 1996, 7, 2233.

19. PC Spartan-Pro, version 1.0; Wavefunction, Inc.: Irvine, CA, 1999.

20. Gaussian 98 (revision A.7); Frisch, M.J.; Trucks, G.W.; Schlegel, H.B.; Scuseria, G.E.; Robb, M.A.; Cheeseman, J.R.; Zakrzewski, V.G.; Montgomery, J.A.; Stratmann, R.E.; Burant, J.C.; Dapprich, S.; Millan, J.M.; Daniels, A.D.; Kudin, K.N.; Strain, M.C.; Farkas, O.; Tomasi, J.; Barone, V.; Cossi, M.: Cammi,
R.; Mennucci, B.; Pmelli, C.; Andano, Clifford, S.; Ochterski, J.; Peterson, G.A.; Ayala, P.Y.; Cui, Q.; Ortiz, J.V.; Baboul, A.G.; Stefanov, BG.B.; Liu, G.; Liashensko, A.; Piskorz, P.; Komarromi, I.; Gomperts, R.; Martin, R.L.; Fox, D.J.; Keith, D.J.; Al-Lahman, M.A.; Peng, C.Y.; Nanyakkara, A.; González, C.; Challacomble, M.; Gill, P.M.W.; Johnson, B.; Chen, W.; Wong, M.W.; Andres, J.L.; González, C.; HeadGordon, M.; Replogle, E.S.; Pople, J.A. Gaussian, Inc.: Pittsburg, PA, 1998.

21. Chang, G.; Guida, W.C.; Still, W.C. J. Am. Chem. Soc. 1989, 111, 4379.

22. (a) Johnson, F.; Malhotra, S.K. J. Am. Chem. Soc. 1965, 87, 5492. (b) Hoffmann, R.W. Chem. Rev. 1989, 89, 1841. (c) See, also: Juaristi, E.; León-Romo, J.L.; Reyes, A.; Escalante, J. Tetrahedron: Asymmetry 1999, 10, 2441.

23. See, for example: Jorgensen, W.L.; Severance, D.L. J. Am. Chem. Soc. 1990, 112, 4768.

24. (a) Streitwieser, A. Acc. Chem. Res. 1984, 17, 353. (b) Streitwieser, A.; Bachrach, S.M.; Dorigo, A.; Schleyer, P.v.R. In Lithium Chemistry: A Theoretical and Experimental Overview; Sapse, A.M.; Schleyer, P.v.R., Eds.; Wiley: New York, 1995; pp 12-15.

25. Brown, H.C.; Kramer, G.W.; Levy, A.B.; Midland, M.M. Organic Synthesis via Boranes; Wiley: New York, 1975; p 256.

26. Juaristi, E.; Martínez-Richa, A.; García-Rivera, A.; Cruz-Sánchez, J.S. J. Org. Chem. 1983, 48, 2603.

27. (a) King, T.E.; Stewart, C.J.; Cheldelin, V.H. J. Am. Chem. Soc., 1953, 75, 1290. (b) Overberger, C.G.; Marullo, N.P.; Hiskey, R.G. J. Am. Chem. Soc. 1961, 83, 1374.

28. NMR spectra were recorded at $100^{\circ} \mathrm{C}$ in order to simplify their appearance, since rotation around the $\mathrm{N}$ $\mathrm{C}=\mathrm{O}$ amide segment is slow at ambient temperature, giving rise to a complex mixture of signals.

29. Balenovic, K.; Bregant, N. Tetrahedron 1959, 5, 44.

Received: May 25, 2001

Published on the web: August 15, 2001 